CUADERNOS DE ESTUDIOS GALLEGOS, LXI Núm. 127 (enero-diciembre 2014), págs. 117-142

ISSN: $0210-847 \mathrm{X}$

DOI: $10.3989 /$ ceg.2014.127.04

\title{
FRANCISCO DE AGUIAR Y SEIJAS, PASTOR DEL REBAÑO
}

\author{
Rocío Silva Herrera
}

Centro de Formación de agentes laicos para acciones específicas de México 


\title{
FRANCISCO DE AGUIAR Y SEIJAS, PASTOR DEL REBAÑO
}

\begin{abstract}
RESUMEN
¿Cuál fue el perfil pastoral de Francisco de Aguiar y Seijas, arzobispo de México? A través de los datos que aporta el Libro de visita de su cuarta salida a las regiones de Chalco, Amilpas, Xochimilco y Coyoacán del 4 de diciembre de 1686 al 9 de abril de 1687, y utilizando la metodología de la biografía temática, se ha dado respuesta a la pregunta inicial. Luego del Concilio de Trento, el obispo tenía el grave deber de suscitar la reforma de las costumbres en su diócesis; la visita pastoral fue un medio privilegiado para lograrlo. El arzobispo Aguiar, formado bajo la disciplina tridentina en la arquidiócesis compostelana, hizo de su visita pastoral una verdadera misión popular entre la gente. Acompañado de una pequeña curia itinerante, gobernó e impartió justicia con características de delegación de poder. Hombre disciplinado, austero y de carácter conciliador se dirigió más como pastor de almas que como funcionario real.

Palabras Clave: Aguiar, Seijas, visita, pastoral, pastor, México.
\end{abstract}

\section{FRANCISCO DE AGUIAR E SEIJAS, PASTOR DO RABAÑO}

\section{RESUMO}

Cal foi o perfil pastoral de Francisco de Aguiar e Seijas, arcebispo de México? A través dos datos que achega o libro de visita da súa cuarta saída ás rexións de Chalco, Amilpas, Xochimilco e Coyoacándo 4 de decembro de 1686 ao 9 de abril de 1687, e utilizando a metodoloxía da biografía temática, se deu resposta á pregunta inicial. Logo do Concilio de Trento, o bispo tiña o grave deber de suscitar a reforma dos costumes na súa diocese; a visita pastoral foi un medio privilexiado para logralo. $\mathrm{O}$ arcebispo Aguiar, formado baixo a disciplina tridentina na arquidiócesis compostelá, fixo da súa visita pastoral unha verdadeira misión popular entre a xente. Acompañado dunha pequena curia itinerante, gobernou e impartiu xustiza con características de delegación de poder. Home disciplinado, austero e de carácter conciliador dirixiuse máis como pastor de almas que como funcionario real.

Palabras Clave: Aguiar, Seijas, pastoral, pastor, México.

\section{FRANCISCO DE AGUIAR Y SEIJAS, SHEPHERD OF THE HERD}

\section{Abstract}

Which was the pastoral profile of Francisco de Aguiar y Seijas, archbishop of Mexico? Through the dates of the Book of visit in his fourth journey in the regions of Chalco, Amilpas, Xochimilco and Coyoacan from december $4^{\text {th }} 1686$ to april $9^{\text {th }} 1687$, and making use of the thematic biography as method, the answer to the initial question has arrived. After the Council of Trent, the bishop had the duty to promote the reform of customs in his diocese; the pastoral visit was a privileged way to achieve it. The archbishop Aguiar, educated from the tridentine discipline in the archdiocese of Santiago de Compostela, made of his pastoral visit a really popular mission among the people. He takes a small itinerant curia, to govern and discharging justice in a delegated manner. A disciplined, austere and conciliator man, he served as a souls shepherd more than a court official.

KEY WORDS: Aguiar, Seijas, visit, pastoral, shepherd, Mexico. 
Recibido/Received: 06/09/2013

Aceptado/Accepted: 08/09/2014

\section{Francisco de Aguiar y SeiJas, PAStor Del REBAÑO ${ }^{I}$}

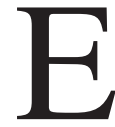

1 objetivo de esta investigación es mostrar el perfil episcopal de Francisco de Aguiar y Seijas, arzobispo de México, durante la ejecución de su ministerio en la cuarta salida de su visita pastoral entre el 4 de diciembre de 1686 y el 9 de abril de 1687 por las regiones de Chalco, Valle de las Amilpas, Xochimilco y Coyoacán.

La principal fuente documental de esta investigación corresponde al tercer Libro que comprende la cuarta cordillera ${ }^{2}$. El volumen está custodiado en el Archivo General de la Nación de México y permanece inédito. Escrito en castellano con letra humanística, consta de 315 fojas escritas por el recto y el verso, cosidas y protegidas por un forro de cuero. Su estado de conservación es relativamente bueno.

Contiene el Edicto de visita firmado por el secretario del arzobispado, Alonso de Aguiar y Lobera. Ofrece una descripción detallada de lo acaecido durante cada jornada guardando siempre un orden estereotipado y cronológico. Al final de los 37 escritos, correspondientes a cada una de las entidades visitadas, se encuentra la firma autógrafa del arzobispo Francisco de Aguiar y Seijas. Se hallan también otros edictos y facultades que el prelado despachó por el camino, firmados por Felipe Desa Ulloa, el notario de la visita. Éste fue el encargado de redactar el Libro, pero se notan dos manos en la escritura, una de ellas más fina, pequeña y apretada.

A los Libros de visita se les puede interrogar desde diversas perspectivas sociales, antropológicas e inclusive eclesiales y religiosas, pero no debe olvi-

\footnotetext{
1 Abreviaturas empleadas: AGI, Archivo General de Indias; AGN, Archivo General de la Nación de México; AHAM, Archivo Histórico del Arzobispado de México; AHPSMO, Archivo Histórico de la Parroquia de Santa María Ozumba, Estado de México; c., cánon; Conc. Trent., Concilio de Trento; D., Decreto; Dec. Grac., Decreto de Graciano; III LVFAS, Tercer Libro de Visita de Francisco de Aguiar y Seijas; IIICPMx, Tercer Concilio Provincial Mexicano; q., cuestión; Rec. Ind., Recapitulación de las Leyes de Indias; Ses., sesión; Sum. Theo., Suma Teológica.

2 Cfr. AGN, Instituciones coloniales, Indiferente virreinal, vol. 1460, exp. 035, fols. 1r-315v. Desde aquí en adelante: III-LVFAS.
} 
darse que la visita es la obra de un hombre de Iglesia ejerciendo sus funciones pastorales $^{3}$.

Otras fuentes inéditas consultadas están contenidas en el volumen México 338 del fondo de Instituciones Metropolitanas del Consejo de Indias del AGI, en el que se encuentran los expedientes originales de la comunicación entre los arzobispos de México con la Corona. Estos documentos permitieron profundizar sobre algunos temas puntuales de la cuarta salida, importantes para destacar las características del gobierno pastoral de Francisco de Aguiar. Para este mismo cometido, ayudó el fondo de la parroquia de Santa María Ozumba, en el actual Estado de México.

Por lo que toca a las fuentes publicadas, éstas corresponden a las visitas de diversos prelados, entre ellos Juan de Mañozca y Zamora, Manuel Fernández de Santa Cruz, Juan Santiago de León Garabito y Alonso de Montúfar, así como a crónicas de autores contemporáneos. También se recurrió a los datos que el padre Lezamis, confesor del arzobispo, ofrece en su biografía dedicada a Aguiar. La transcripción de las citas literales se ha hecho respetando el texto.

Para este estudio sobre la persona de Francisco de Aguiar y Seijas, en tanto pastor de almas, se utilizó la metodología de la biografía temática, la cual pide presentar al sujeto histórico en su propio contexto para explicarlo desde sus propios modelos históricos; así como la reducción de la escala de análisis a un determinado aspecto de su vida ${ }^{4}$. Del mismo modo, se siguió el método comparativo para puntualizar la originalidad de la persona en estudio en contraste con ciertas instituciones y prelados contemporáneos ${ }^{5}$. Además, se recurrió al método hermenéutico para interpretar las fuentes a las que se tuvo acceso y que de ninguna manera agotan la comprensión de la vida del arzobispo.

La gestión pastoral de Francisco de Aguiar durante sus visitas pastorales a la diócesis de Michoacán ha sido abordada por Alberto Carrillo ${ }^{6}$. Berenice Bravo y

\footnotetext{
3 Cfr. Nicole Coulet, Les visites pastorales, Turnhout-Belgium, Brepols, 1977, págs. 60-69 (Colecc. Typologie des sources du moyen âge occidental, XXIII).

${ }^{4}$ Cfr. Hans E. BöDEKER, «La biografía como un problema historiográfico» en G. VERA (coord.), Los historiadores y la Historia para el siglo XXI, México, Escuela Nacional de Antropología e Historia, 2006, págs. 324-326; François Dosse, El arte de la biografía, México, Universidad Iberoamericana, 2007, págs. 320-375.

5 Cfr. Magnus LundBerg, Unificación y conflicto. La gestión episcopal de Alonso de Montúfar OP, Arzobispo de México, 1554-1572, tr. Alberto Carrillo Cázares, Zamora, El Colegio de Michoacán, 2009, págs. 27-30.

6 Cfr. Alberto CARriLlo, Michoacán en el otoño del siglo XVII, Zamora, El Colegio de Michoacán, 1993, págs. 9-21; 491. El contenido del primer apartado de esta obra, con algunas ampliaciones y correcciones, también fue publicado en: Alberto CARrILlo, «El obispo Aguiar y Seixas: su perfil pastoral en Michoacán: 1678-1682», en Josefina Muriel, El Arzobispo Francisco de Aguiar y Seijas, México, CARSO, 2000, págs. 27-46.
} 
Marco Antonio Pérez han ofrecido una visión introductoria de la primera salida a visita del arzobispo por la zona de la Huasteca hasta el puerto de Tampico ${ }^{7}$.

\section{EL DEBER DE LA VISITA PASTORAL}

En la tradición eclesial católica los obispos ocupan el lugar de los apóstoles ${ }^{8}$. El ejercicio de su ministerio episcopal debe estar acorde con el modelo de Cristo El Buen Pastor ${ }^{9}$. Por lo que toca a la visita del obispo a su diócesis, desde antaño, se insistió que el mismo prelado la efectuara ${ }^{10}$. Los objetivos eran: informarse sobre el estado de vida espiritual de los clérigos y laicos, y sobre las condiciones materiales y administrativas de todo lo destinado a lo sacro ${ }^{11}$.

El problema que más ensombreció el ejercicio pastoral de la visita a las diócesis fueron los excesivos gastos que se generaban ${ }^{12}$; por tanto, se normó para que el cortejo episcopal no se quedase más de un día en cada parroquia; para que los alimentos ofrecidos fueran moderados y para que jamás se aceptara dinero bajo ningún motivo ${ }^{13}$. El Concilio de Trento fortaleció el gobierno de los obis$\operatorname{pos}^{14}$; en este sentido, la visita pastoral a la diócesis fue uno de los medios más eficaces para concretar el proyecto de reforma de las costumbres ${ }^{15}$.

Por su parte, Felipe II proveyó continuas disposiciones con el afán de que la reforma tridentina se aplicara en todo su imperio ${ }^{16}$. Para el caso específico de

\footnotetext{
7 Cfr. Berenice Bravo y Marco Antonio Perez, «Tiempos y espacios religiosos novohispanos: La Visita Pastoral de Francisco Aguiar y Seijas (1683-1684)» en Alicia Mayer y E. de la Torre (eds.), Religión Poder y Autoridad en la Nueva España, México, Universidad Nacional Autónoma de México, 2004, págs. 67-83.

8 Cfr. Dec. Grac., D. LXVIII, c. 6. Los cánones del Decreto de Graciano fueron tomados de: Corpus juris canonici emendatum et notis illustratum, pars. I, vol. I, Romae, Gregorii XIII. pont. Max. iussu editum, 1582, disponible en <http://digital.library.ucla.edu/canonlaw/> [Consulta: 27.06.2011].

9 Sum. Theo., II-II, q. 184, a. 5. La traducción al español de la obra del Doctor Angélico fue consultada en Tomás de Aquino, Suma de teología IV, Parte II-II (b), Madrid, Biblioteca de Autores Cristianos, $1997^{2}$.

${ }^{10}$ Cfr. Dec. Gra., c. 9; c. 10, q. 1; 12.

${ }^{11}$ Cfr. Dec. Gra., c. 9; c. 10, q. 1; 12.

${ }^{12}$ Cfr. N. Coulet, Les visites pastorales..., pág. 22.

${ }^{13}$ Cfr. Dec. Gra., c. 10, q. 3, c. 8.

${ }^{14}$ Cfr. Conc. Tren., Ses. XXIII, cap. IV. Los textos en latín se tomaron de: Giuseppe Alberigo (ed.), Conciliorum Oecumenicorum Decreta, Bologna, Edizioni Dehoniane, 1991. Los textos traducidos al español de: El sacrosanto y ecuménico concilio de Trento, tr. Ignacio López de Ayala, París-México, Librería de CII. Bouret, s/f.

${ }^{15}$ Conc. Trent., Ses. XXII, Decretum de observandis et vitandis in celebratione missarum; Ses. XXIV, Dec. Ref., cap. III y IV; Ses. XIII, Dec. Ref., cap. I.

${ }^{16}$ Cfr. José Luis Mora, «La visita eclesiástica como institución en Indias», en Richard Konetzke (ed.), Jahrbuch für Geschichte von Staat Wirtschaft und Gesellschaft Lateinamerikas, Wien, Böhlau Verlag Köln, 1980, pág. 61.
} 
sus reinos en las Indias, se debe tener en cuenta el Regio Patronato, por el que el obispo indiano era también un funcionario real ${ }^{17}$. Las Leyes de Indias disponían que era menester el juramento de fidelidad a la Corona por parte del prelado, antes de entregarle sus cartas de presentación ${ }^{18}$. Luego de realizar la visita pastoral el obispo debía remitir un informe completo a la Metrópoli ${ }^{19}$. El III Concilio Provincial Mexicano insistió en el cuidado que el ministro se debía a sí mismo para alcanzar una vida virtuosa, pues la probidad moral del pastor era prototipo de vida para las ovejas ${ }^{20}$.

\section{ORÍGENES GALLEGOS}

Francisco de Aguiar y Seijas nació el 11 de febrero de 1632 en la ciudad de Betanzos de los Caballeros del Reino de Galicia ${ }^{21}$. La carta de Doña Juana María de Aguiar Andrade y Ulloa, sobrina nieta de don Francisco, hecha manifiesta el 20 de julio de 1742 para el proceso de virtudes y milagros de su tío-abuelo, ofrece una síntesis de los momentos académicos y pastorales que marcaron la vida del prelado antes de viajar a la Nueva España: los estudios de gramática los realizó en su tierra de origen, en la escuela de Latinidad y Humanidades, luego pasó al Colegio Mayor de Santiago de Alfeo de Compostela; llegó a ser canónigo lectoral en Astorga y penitenciario en Compostela ${ }^{22}$.

En el Colegio Mayor de Santiago, conocido también como Colegio de Fonseca, Francisco de Aguiar fue formado bajo las directrices tridentinas que habían sido aplicadas en la arquidiócesis jacobea desde 1576 por el arzobispo Francisco Blanco $^{23}$. Los colegios mayores aseguraban la limpieza de sangre del individuo y un título académico; constituían un semillero de la élite eclesiástica secular, habilitada para cubrir una infinidad de puestos en la Iglesia hispana y novohispana ${ }^{24}$.

${ }^{17}$ Cfr. Antonio Dougnac, Manual de historia del Derecho Indiano, México, Instituto de Investigaciones Jurídicas-Universidad Nacional Autónoma de México, 1994, pág. 295; Alberto HerA, Iglesia y corona en la América española, Madrid, MAPFRE, 1992, págs. 175-191.

${ }^{18}$ Cfr. Rec. Ind., L. I, tit. VII, ley I. Todos los textos de Las Leyes de Indias han sido tomados de: Recopilación de las Leyes de Indias, Archivo Digital de la legislación en el Perú, disponible en $<$ http://www.congreso.gob.pe/ntley/LeyIndiaP.htm> [01.03.2011].

${ }^{19}$ Cfr. Rec. Ind., L. I, tit. VII, ley XXIV.

${ }^{20}$ Cfr. III CPMx, L. III, tit. I, Del oficio y entereza de vida de los obispos. Los textos del III Concilio provincial mexicano han sido consultados de: Alberto Carrillo (ed.), Manuscritos del Concilio tercero provincial mexicano (1585), t. III, vol. 1, Zamora, El Colegio de Michoacán, 2009.

${ }^{21}$ AHAM, Provisorato, Causa de beatificación, caja 59, exp. 2, fol. 69r.

${ }^{22}$ Cfr. Manuel Troitiño, Vida del Ilmo. Sr. Don Francisco de Aguiar y Seixas, Santiago, E.U.C., 1951, págs. 39, 46.

${ }^{23}$ Cfr. Carlos Santos, "Un volumen de constituciones sinodales compostelanas del siglo XVII en la Biblioteca del Seminario Mayor Divino Maestro de Ourense”, Auriensia, 12 (2009), pág. 242.

${ }^{24}$ Cfr. Arturo Iglesias, El cabildo catedralicio de Santiago de Compostela en el siglo XVI: aspectos funcionales y sociológicos de una élite eclesiástica, Santiago de Compostela, Universidad de 
El 11 de enero de 1677, siendo canónigo penitenciario, Francisco de Aguiar avisó al cabildo compostelano de su presentación para la mitra de Guadalajara en la Nueva Galicia, pero el 23 de febrero participó que su nombramiento era para la sede de Michoacán ${ }^{25}$.

\section{Visita GENERAL AL ARZOBISPAdo DE MÉXICO}

El preconizado obispo tomó posesión de su mitra el domingo $1^{\circ}$ de enero de $1679^{26}$. A los dos años de haber asumido la mitra de Michoacán, mientras hacía su visita pastoral, recibió la noticia de su presentación para el arzobispado de México, junto con la letra apostólica que le desligaba de su matrimonio espiritual con la diócesis de Michoacán para rehacerlo con la de México $^{27}$. La ceremonia de toma de sede se realizó el lunes 23 de noviembre de $1682^{28}$. Aguiar escribió una escueta carta al rey para informar del acto ${ }^{29}$.

En aquel entonces, la jurisdicción arquidiocesana tenía aproximadamente 140 leguas desde el puerto de Tampico hasta el puerto de Acapulco ${ }^{30}$. El arzobispo Aguiar decidió iniciar la visita general en su vasto territorio en $1683^{31}$.

Su visita general la ejecutó en cinco cordilleras periódicas y consecutivas. La primera salida la hizo del 3 de noviembre de 1683 al 9 de junio de 1684, en ella recorrió la zona más lejana de la sede episcopal, a saber, la Sierra Baja, la Huasteca, la Custodia de Tampico y la Sierra Alta ${ }^{32}$. La segunda cordillera se inició el 21 de noviembre de 1684 y concluyó el 13 de junio de $1685^{33}$; en aquella

Santiago de Compostela, 2010, págs. 372-375; Andrés Melquiades, La teología española en el siglo XVI, t. II, Madrid, Biblioteca de Autores Cristianos, 1977, pág. 211.

${ }^{25}$ Cfr. Antonio López, Historia de la Santa A. M. Iglesia de Santiago de Compostela, t. IX, Santiago de Compostela, Seminario Conciliar Central, 1907, pág. 275.

${ }^{26}$ Cfr. A. CARrillo, «El obispo Aguiar y Seixas...», en op.cit., pág. 30.

${ }^{27}$ Cfr. AGI, MP-Bulas_Breves, 187, fols. 1r-2r; AHAM, Secretaría Apostólica, Letras apostólicas, caja 12 , exp. 49, fols. 1r-2v.

${ }^{28}$ Cfr. Antonio Robles, Diario de sucesos notables (1665-1703), t. II, México, Porrúa, 19722, pág. 32.

${ }^{29}$ Cfr. AGI, Instituciones Metropolitanas del Consejo de Indias, México 338, Cartas y expedientes de los arzobispos de México, Aviso de toma de posesión del arzobispado, 26 de diciembre de 1682, fol. $1 \mathrm{r}$.

${ }^{30}$ Cfr. Antonio Vázquez, Descripción de la Nueva España, Mariano Cuevas (ed.), México, Patria, 1944, pág. 130.

${ }^{31}$ Cfr. AGI, Instituciones Metropolitanas del Consejo de Indias, México 338, Cartas y expedientes de los arzobispos de México, El arzobispo avisa haber recibido el sagrado palio arzobispal, 29 de junio de 1683 , fol. $1 \mathrm{r}$.

${ }^{32}$ Cfr. AHAM, Secretaría arzobispal, Visitas, CL 19, L 1, fols. 1r-208r. Durante su gobierno en Michoacán también había dado inicio a su visita pastoral por la zona más alejada de Valladolid: las recién fundadas misiones de Río Verde; cfr. A. CARriLlo, «El obispo Aguiar y Seixas...», en o.c., pág. 32.

${ }_{33}$ Cfr. AHAM, Secretaría arzobispal, Visitas, CL 19, L 1, fols. 213r-695r. 
ocasión salió por el lado de Tacubaya rumbo al Valle de Toluca. El tercer recorrido comenzó el 9 de noviembre de 1685, tomando la ruta de Cuautitlán-TepejiQuerétaro, y lo concluyó el día 19 de abril de $1686^{34}$. La cuarta cordillera, que es el objeto de esta investigación, fue hecha entre el 4 de diciembre de 1686 y el 9 de abril de 1687 por las zonas de Chalco, el Valle de las Amilpas, Xochimilco y Coyoacán ${ }^{35}$. Finalmente, la quinta salida dio comienzo el 26 de noviembre de 1687 y finalizó el 24 de enero de $1688^{36}$. Tenía previsto llegar hasta el Puerto de Acapulco, pero no lo logró a causa de su precario estado de salud; de esta manera dio por concluida su visita general ${ }^{37}$.

El arzobispo sabía la trascendencia de hacer la visita por sí mismo y así lo expresó al rey al decirle que para los fieles era un gran consuelo ver a su pastor en medio de sus tierras ${ }^{38}$.

\section{ESPACIO Y TIEMPO DE LA ZONA VISITADA EN LA CUARTA CORDILLERA}

El arzobispo estuvo en pueblos y villas pertenecientes a las demarcaciones de Chalco, Amilpas, Xochimilco y Coyoacán, todas ellas atendidas por religiosos franciscanos, dominicos y agustinos ${ }^{39}$. Se trataba de zonas de cultivo, ganaderas, de comercio; con un gran número de haciendas, ingenios, ranchos y trapiches; habitada en su mayoría por indios, con una discreta población española y un notable número de esclavos negros ${ }^{40}$.

\footnotetext{
${ }^{34} \mathrm{Cfr}$. AGN, Instituciones coloniales, Regio patronato indiano, Bienes nacionales, vol. 475, exp. 1, fols. $1 \mathrm{v}-368 \mathrm{r}$.

${ }^{35}$ Cfr. III-LVFAS, fols. 1-315. El inicio de esta cordillera la omitió Antonio Robles y el bachiller Rosales la refiere de manera confusa; cfr. A. RoBles, Diario de sucesos notables..., págs. 131; 137; Bartolomé Rosales, Diario 1683-1688, en Estudios de historia novohispana Vol. XXXVIII (2008), transcripción y notas Benedetta Albani, México, Universidad Nacional Autónoma de México, pág. 204.

${ }^{36}$ El libro correspondiente a esta quinta cordillera, aún no se ha encontrado, pero se sabe que la hizo por carta del mismo arzobispo y por las crónicas contemporáneas: cfr. AGI, Instituciones Metropolitanas del Consejo de Indias, México 338, Cartas y expedientes de los arzobispos de México, Por lo del casamiento de los fieles por sus curas sin licencia del obispo, México 26 de mayo de 1688, fol. 3r; A. Robles, Diario de sucesos notables..., págs. 151; 154; B. Rosales, Diario..., pág. 205. ${ }^{37}$ Cfr. AGI, Instituciones Metropolitanas del Consejo de Indias, México 338, Cartas y expedientes de los arzobispos de México, El arzobispo de México da cuenta a VM de haber concluido la visita del arzobispado, México 31 mayo 1688, fol. 1r.

${ }^{38}$ Cfr. Mariano Cuevas, Historia de la Iglesia en México 1600-1699, t. III, México, Cervantes, 19424, págs. 104-105.

${ }^{39}$ Cfr. III-LVFAS, fols. 1-315.

${ }^{40}$ Cfr. Rebeca Horn, Postconquest Coyoacan. Nahua-Spanish relations in Central Mexico, 15191650, Stanford, Stanford University Press, 1997, págs. 1; 205; 213; 215-219; 223; Tomás JALPA, La sociedad indígena en la región de Chalco durante los siglos XVI y XVII, México, Instituto Nacional de Antropología e Historia, 2009, pág. 140; Manuel Mĩ̃o, El mundo novohispano. Población, ciudades y economía, siglos XVII y XVIII, México, Colegio de México-Fondo de Cultura Económica,
} 
A las ocho de la mañana del miércoles 4 de diciembre de 1686, con repique de campanas, el arzobispo salió de su palacio hacia la catedral acompañado del cabildo catedralicio y miembros de la audiencia ${ }^{41}$. De acuerdo con el Edicto de visita, originalmente visitaría 30 doctrinas, un beneficio y los ingenios de la región de Cuautla de las Amilpas, pero luego de dos modificaciones por el camino, el prelado finalmente visitó un total de 35 doctrinas y un beneficio; nueve ingenios, un trapiche, una hacienda de labor y dos hospitales ${ }^{42}$.

Por razones prácticas, Aguiar hizo sus cinco salidas durante los meses exentos de lluvias; sin embargo, cada vez, este período estacional comprendió ciclos litúrgicos importantes. En el año de 1686, el I Domingo de Adviento se celebró el $1^{\circ}$ de diciembre y la Pascua de 1687 , el 30 de marzo ${ }^{43}$. Es decir, la cuarta cordillera dio inicio en Adviento y terminó en Pascua, incluyendo en ella Navidad y Cuaresma. La visita pastoral de Aguiar adquirió en sí una significación particularmente cristológica y salvífica, a causa del marco litúrgico de la Iglesia universal en el que se inscribió.

El tiempo que permaneció el arzobispo en cada doctrina fue muy variado. Al beneficio de San Mateo Churubusco llegó a las 10:00 horas y se retiró a las 17:00 hrs; en cambio, en Xochimilco, donde pasó la Semana Santa, se quedó ocho días ${ }^{44}$. Lo cierto es que cada día, Francisco de Aguiar cumplió con una apretada y bien organizada agenda ${ }^{45}$. En el siguiente cuadro se muestra su horario habitual:

\begin{tabular}{|c|c|}
\hline Hora & Actividad \\
\hline 4:00 0 5:00 & Maitines. \\
\hline 6:00 & Celebración de la Eucaristía. Oración. Despachos varios. \\
\hline 7:00 & Desayuno. Rezo de Prima y Sexta. \\
\hline 9:00 a 12:00 & Confirmaciones. Oración. Despachos varios. \\
\hline 12:00 & Comida. Descanso. \\
\hline 15:00 a 18:00 & Confirmaciones. Vísperas. \\
\hline 18:00 a 19:00 & Despachos varios. \\
\hline 19:00 & Angelus y rosario. Plática espiritual. Oración y descanso. \\
\hline
\end{tabular}

2001, pág. 139; Juan Manuel PÉrez, Xochimilco ayer, México, Instituto Mora, 2002, págs. 11-13; Ernest SANTIRó, "Plata y privilegios: el Real de Minas de Huautla, 1709-1821", Estudios de Historia Novohispana, 26 (2002), México, Instituto de Investigaciones Históricas-Universidad Nacional Autónoma de México, pág. 87.

${ }^{41}$ Cfr. III-LVFAS, fols. 2v-3r.

${ }^{42}$ Cfr. III-LVFAS, fols. 1r-1v; 24v-25r; 226v-227r.

${ }^{43}$ Cfr. Adriano CAPPelli, Cronologia. Cronografia e Calendario perpetuo, Milano, HOEPLI, $1998^{7}$, págs. 52,83 .

${ }^{44}$ Cfr. III-LVFAS, fols. 297v-301v.

${ }^{45}$ El horario del Libro de visita se confrontó con el que ofrece el padre Lezamis, y coinciden; cfr.

J. LeZAMIs, Breve relación de la vida y muerte..., págs. 45-47; 60-61. 
Esta jornada de trabajo es muy similar a la de Manuel Fernández de Santa Cruz cuando estaba de visita ${ }^{46}$. Los horarios de ambos prelados muestran un equilibrio entre el cuidado de su propia alma y sus acciones ministeriales, tal y como lo recomendó el III Concilio Provincial Mexicano ${ }^{47}$.

La apretada agenda del arzobispo y la ausencia de contratiempos en su desplazamiento, permitieron que el tiempo de la visita fuera bien aprovechado, pero las jornadas resultaron agotadoras, como lo fue desde la primera salida ${ }^{48}$.

\section{EL RITO LITÚRGICO DE LA VISITA}

Al comparar el modo de visita que guardó Aguiar, con el que ofrece el Ordo ad visitanda parochias del Pontifical Romano de Clemente VIII (1595) ${ }^{49}$, se nota un acomodo bastante libre de algunas de sus partes; no obstante, el orden de visita: sagrario - pila bautismal - sacristía, lo siguió escrupulosamente ${ }^{50}$.

Al respecto, la única observación grave que hizo Aguiar sobre el decoro fue en San Marcos Tlayecac, doctrina agustina, donde no había sagrario. Para remediar esta omisión, pidió al padre provincial de los agustinos, Diego Velásquez de la Cadena, proveer de un tabernáculo ${ }^{51}$.

Fuera de esto, no se nota una escrupulosa exigencia de parte de Francisco de Aguiar por la compostura de los lugares y vasos sagrados. En cambio, en la memoria de visita del obispo Garabito en la Nueva Galicia (1678) se percibe una extrema preocupación del prelado por la dignidad de los lugares, vasos y ornamentos sagrados. Por ejemplo, en el beneficio de Mezquitán mandó que un cuadro de San Miguel arcángel ubicado en el altar mayor se quitara para borrarle el dragón y, mientras se hacía ese trabajo, debía colocarse en su lugar el San Miguel de talla ${ }^{52}$.

\footnotetext{
${ }^{46}$ Cfr. Miguel de Torres, Dechado de príncipes eclesiásticos. Que dibujó con su exemplar, virtuosa y ajustada vida el Ilust. y Exc. Señor Doctor D. Manuel Fernandez de S. Cruz, y Sahagún, ed. facsimilar, México, Sociedad Mexicana de Bibliófilos, 1999, págs. 137-139.

${ }^{47}$ Cfr. III CPMx, L. III, tit. I, Del oficio y entereza de vida de los obispos.

${ }^{48}$ Cfr. J. LeZamis, Breve relación de la vida y muerte..., pág. 64.

${ }^{49}$ Cfr. Pontificale Romanum Clementis VIII Pont. Max. iussu restitutum atque, Roma, Leonardi Parasoli \& Sociorum (ed.), Giacomo Luna (imp.), 1595, págs. 663-671.

${ }^{50}$ Cfr. III-LVFAS, fols. 97r; 151r; 154r; 167r; 274r.

${ }^{51}$ Cfr. III-LVFAS, fols. 97r-v.

${ }^{52}$ Cfr. "El Libro de Visita pastoral del obispo Garabito o semblanza de la Nueva Galicia en 1678", Boletín eclesiástico. Órgano oficial de la Arquidiócesis de Guadalajara, vol. 120/ 1 (2009), págs. 37-39.
} 


\section{LA VISITA COMO MISIÓN POPULAR}

Aguiar rezaba diario el rosario a coro con sus familiares en la iglesia del lu$\operatorname{gar}^{53}$. Se debe decir que para el obispo de Puebla, Manuel Fernández, el rezo del rosario en sus visitas no era prioritario como para Aguiar, pues si las actividades del día no habían permitido que se rezara en la iglesia, el obispo angelopolitano lo hacía de manera privada con sus familiares ${ }^{54}$. La piedad mariana del arzobispo, hecha manifiesta en público, fue una de las acciones misioneras de la visita, por medio de ésta fortaleció la devoción de los fieles.

Por lo que toca a las pláticas espirituales de misión, éstas se terciaban entre Aguiar y el padre José Capetillo ${ }^{55}$, el predicador que le acompañó. No se ha podido encontrar ningún sermón del arzobispo, pero Lezamis dice al respecto que el estilo del arzobispo era claro, sencillo y grave, utilizaba ejemplos para que quedara en la memoria de la gente menuda ${ }^{56}$.

También se organizaron varias procesiones nocturnas de sangre y penitencia, en las que se incluyeron pláticas espirituales y saetas ${ }^{57}$. Aquel escenario dispuesto, tanto por el equipo de trabajo del arzobispo como por los lugareños, el tono de elegía propio de las saetas, la oscuridad alumbrada por las antorchas, el ambiente penitencial y el arzobispo acompañando personalmente la procesión, debió ser auténticamente una saeta espiritual clavada en el alma de los fieles causándoles compunción por sus pecados.

\section{REFORMA DE LAS COSTUMBRES}

Sobre el correcto porte de los laicos en los lugares sagrados, la mayor parte de las llamadas de atención las hizo a los feligreses de varias doctrinas dominicas; éstas tocaron aspectos que tenían que ver con la vestimenta, los peinados y el recato ${ }^{58}$.

La llamada de atención más recurrente y severa fue respecto al uso de los temascales. Aguiar dispuso que bajo ninguna circunstancia se bañaran juntos hombres y mujeres en aquellos baños públicos prehispánicos, a menos que fue-

\footnotetext{
${ }^{53}$ Cfr. III-LVFAS, fols. 34v; 48v; 78r; 96v; 101r; 123r-v.

${ }^{54}$ Cfr. M. de Torres, Dechado de príncipes eclesiásticos..., págs. 137-139.

${ }^{55}$ Cfr. III-LVFAS, fols. 4r; 15r; 31v; 39r; 46r; 61r; 75v; 77r; 87r; 96v; 108v; 120v; 123v; $128 \mathrm{r}$; 130v; 144r; 149r; 153r; 156r; 176v; 179r; $180 \mathrm{r}-\mathrm{v} ; 186 \mathrm{v} ; 187 \mathrm{v} ; 189 \mathrm{v} ; 195 \mathrm{r} ; 199 \mathrm{v} ; 211 \mathrm{r} ; 217 \mathrm{r} ; 226 \mathrm{r}$; $234 \mathrm{v} ; 237 \mathrm{v} ; 246 \mathrm{v} ; 260 \mathrm{v} ; 263 \mathrm{v} ; 266 \mathrm{r} ; 269 \mathrm{v}-270 \mathrm{r} ; 273 \mathrm{v} ; 293 \mathrm{r}$.

${ }^{56}$ Cfr. J. LezAmis, Breve relación de la vida y muerte..., pág. 59.

${ }^{57}$ Cfr. III-LVFAS, fols. 137v; 168v; 189v; 226r; 232r; 288r; 311r.

${ }^{58}$ Cfr. III-LVFAS, fols. 167r; 210r; 313r-v
} 
ran esposos ${ }^{59}$. Esta aversión contra los temascales no era una antipatía exclusiva del prelado, sino de ciertos sectores de la sociedad novohispana, los cuales creían que estos espacios favorecían los adulterios y otros pecados que atentaban contra las buenas costumbres ${ }^{60}$.

Dada la mucha distancia que había entre el lugar de labor y la cabecera de la doctrina, así como la negativa de los patrones para dejar salir a sus empleados y esclavos a cumplir con sus deberes píos, situación que persistía desde fines del siglo $\mathrm{XVI}^{61}$, el arzobispo dispensó una gran cantidad de permisos, tanto refrendas como nuevas licencias, para celebrar misa y otros sacramentos, en las capillas de las haciendas e ingenios ${ }^{62}$. Con estos permisos cubrió un aspecto importante para lograr la reforma de las costumbres, decretada por el Concilio de Trento: acercar a las personas a la vida sacramental.

En este mismo sentido, otro problema que atendió el arzobispo fue el considerable número de las fiestas de guardar. Para remediar esta dificultad ya había intentado aplicar una bula de Urbano VIII por la que se reducían las misas de precepto, pero recibió gran oposición, ya que el documento no había sido aprobado por el Real Consejo. Por tanto, Aguiar escribió al rey desde la doctrina agustina de Totolapan, la cuarta en su itinerario, para solicitarle que se admitiera la publicación del documento pontificio (véase doc. del Anexo documental).

Los permisos dados por el arzobispo para la celebración de los sacramentos en los ingenios y haciendas favorecían la retención de los esclavos para evitar su fuga, pero también indican su preocupación porque la población negra accediera a los sacramentos y a la celebración del culto público. La situación de los esclavos, que implicaba factores de tipo social, económico y religioso, Aguiar la afrontó con tacto pastoral.

\footnotetext{
${ }^{59}$ Cfr. III-LVFAS, fols. 122r; 140v; 150v; 157r; 167r; 176r; 182r; 188r-v; 210r; 238v; 250r; 265v; $274 \mathrm{v} ; 290 \mathrm{r}-\mathrm{v}$.

${ }^{60}$ Cfr. Natalia Silva, "El uso de los baños temascales en la visión de dos médicos novohispanos. Estudio introductorio y transcripción documental de los informes de 1689", Historia Mexicana Vol. LII/1 (2002), México, Revista Trimestral publicada por el Centro de Estudios Históricos de El Colegio de México, págs. 5-30.

${ }^{61}$ III CPMx, L. II, tit. III, §5; Cristina MASFERrer, "Agua de blancos: bautismo de negros. Las actas bautismales de negros y castas del Sagrario Metropolitano de la ciudad de México", en Doris Bienko y Berenice Bravo (coords.), De sendas, brechas y atajos. Contexto y crítica de la fuentes eclesiásticas, siglos XVI-XVIII, México, Escuela Nacional de Antropología e Historia, 2008, págs. 197-209.

${ }^{62}$ Cfr. III-LVFAS, fols. 17v; 60r-61v; 65r-v; 77r; 81r-v; 180r; 189r-v.
} 


\section{LAS CONFIRMACIONES}

El Concilio de Trento declaró que los obispos eran los ministros ordinarios y exclusivos de los sacramentos de la confirmación y del orden ${ }^{63}$. Esta potestad fue ejercida por Francisco de Aguiar de manera copiosa durante su cuarta cordillera. En total confirmó a 34,968 fieles, de quienes no recibió ofrenda alguna ${ }^{64}$.

En promedio confirió el sacramento a 280 personas por día, sin embargo, hubo jornadas en las que no confirmó a nadie a causa de sus traslados de una doctrina a otra, o simplemente porque no hubo demandantes, como sucedió en la doctrina dominica de Amecameca ${ }^{65}$, pero en San Agustín Xonacatepec, atendida por los agustinos, llegó a confirmar a 704 de una sola vez ${ }^{66}$. Además, se apeó en dos ocasiones de manera espontánea, una en Santa María Xalostoc para confirmar a 178 personas ${ }^{67}$, y otra en Anenecuilco para confirmar a sólo dos fieles ${ }^{68}$.

Todas estas confirmaciones retratan su honda preocupación por fortalecer a los creyentes que estaban bajo su custodia, no importando la logística que de improviso debía desplegarse en el lugar para efectuar el rito sacramental con el decoro necesario.

\section{LA ENSEÑANZA DE LA DOCTRINA CRISTIANA}

La atención de Francisco de Aguiar por la instrucción de su feligresía en las verdades de la fe cristiana se manifestó en la promoción del ministerio de los fiscales, laicos responsables de juntar a los niños y adolescentes para explicarles la doctrina y aprender las oraciones ${ }^{69}$.

La descripción que hace el Libro sobre el método catequético recuerda al utilizado por los frailes durante la etapa de la evangelización fundante, es decir, aquellos jóvenes indios instruidos por los frailes que en sus pueblos, reunían a la gente para enseñarles la doctrina y las oraciones ${ }^{70}$. Así mismo, la narración que

\footnotetext{
${ }^{63}$ Cfr. Carlo Fantappiè, "Il concilio di Trento e la reforma pastorale", en Introduzione storica al diritto canonico, Bologna, il Mulino, 2003, pág. 147; Jean GAudemet, Storia del diritto canonico. Ecclesia et Civitas, Milano, San Paolo, 1998, pág. 480.

${ }^{64}$ En el archivo de la parroquia de Santa María Ozumba se encuentra la matrícula de los 570 confirmados por Aguiar entre el domingo 23 y el lunes 24 de febrero de 1687; cfr. AHPSMO, Sacramental, Bautismos, caja 1, exp. 04, fols. 1r-3v.

${ }^{65}$ Cfr. III-LVFAS, fol. 280v.

${ }^{66}$ Cfr. III-LVFAS, fol. 100r.

${ }^{67}$ Cfr. Cfr. III-LVFAS, fol. 96v.

${ }^{68}$ Cfr. Cfr. III-LVFAS, fols. 92v-93r.

${ }^{69}$ Cfr. III-LVFAS, fol. 29v.

${ }^{70}$ Cfr. Robert Ricard, La conquista espiritual de México. Ensayo sobre el apostolado y los métodos misioneros de las órdenes mendicantes en la Nueva España de 1523-1524 a 1572. México, Fondo de Cultura Económica, 1999, págs. 181-189.
} 
ofrece el Libro sobre la instrucción a las niñas muestra que de alguna manera éstas vivían en un cierto régimen de internado, en este sentido, se debe recordar que las escuelas para las niñas indias respondieron a las necesidades de la segunda etapa de la evangelización ${ }^{71}$. Para el arzobispo, estos métodos catequéticos, utilizados desde el siglo XVI, continuaban siendo necesarios y efectivos para apoyar la pastoral en la última década del siglo XVII.

Antes de salir a su cuarta cordillera, el prelado había recibido una cédula real en la que se ordenaba que los indios recibieran su formación cristiana en castellano $^{72}$. El arzobispo expuso al rey, apelando a su experiencia de las anteriores visitas, que quienes enseñaban la doctrina a los naturales en su lengua natal, tanto en los beneficios como en las doctrinas, eran los fiscales y sacristanes, los cuales eran indios, porque casi no había españoles; afirmó también que muchos de los catequistas sabían la lengua castellana, pero no querían hablarla ${ }^{73}$. Esta resistencia a hablar el castellano también la hicieron notar los obispos de Puebla, Oaxaca y Nueva Galicia, en su momento ${ }^{74}$.

Aguiar sugirió que para efectuar el real mandato, el soberano tendría que pagar el salario a los maestros españoles, en primer lugar porque la pobreza en la que se hallaban los indios apenas les alcanzaba su trabajo para el sustento y en segundo, los maestros españoles no querían enseñar de balde ${ }^{75}$.

La Metrópoli no cejó en su intento; con cédula del 16 de febrero de 1688, se le pidió a Aguiar que ordenara a los curas doctrineros que los fiscales y sacristanes encargados de la enseñanza de la doctrina lo hicieran en castellano; el prelado respondió, al año siguiente de manera lacónica, que haría los despachos correspondientes ${ }^{76}$.

${ }^{71}$ Cfr. Josefina Muriel, La sociedad novohispana y sus colegios de niñas. Fundaciones del siglo XVI, t. I, México, Instituto de Investigaciones Históricas-Universidad Nacional Autónoma de México, 2004, págs. 105-108.

${ }^{72}$ Cfr. AGI, Instituciones Metropolitanas del Consejo de Indias, Cartas y expedientes de los arzobispos de México, México 338, Que a los indios se les enseñe el castellano y en esa lengua se les instruya en la doctrina cristiana, México $1^{\circ}$ de diciembre de 1686 , fol. $1 \mathrm{v}$.

73 cfr. AGI, Instituciones Metropolitanas del Consejo de Indias, México 338, Cartas y expedientes de los arzobispos de México, Sobre la enseñanza del castellano y de la doctrina cristiana a los indios, México 15 agosto 1687, fol. 1r.

${ }^{74}$ Cfr. Dorothy TANCK DE EsTRADA, "Castellanización, política y escuela de indios en el arzobispado de México a mediados del siglo XVIII”, en Historia Mexicana, vol. XXXVIII/4 (1989), México, Revista Trimestral publicada por el Centro de Estudios Históricos de El Colegio de México, pág. 705 .

75 AGI, Instituciones Metropolitanas del Consejo de Indias, México 338, Cartas y expedientes de los arzobispos de México, Que a los indios se les enseñe el castellano y en esa lengua se les instruya en la doctrina cristiana, México $1^{\circ}$ de diciembre de 1686, fol. $1 \mathrm{r}$.

${ }^{76}$ Cfr. AGI, Instituciones Metropolitanas del Consejo de Indias, México 338, Cartas y expedientes de los arzobispos de México, Sobre la enseñanza del castellano y de la doctrina cristiana a los 
En este punto, se debe recordar que, desde 1550, la Corona había solicitado la enseñanza de la doctrina cristiana a los indios en castellano para que comprendieran de mejor forma los misterios de la fe, dejaran sus idolatrías y asimilaran la cultura española. A pesar de ello, la praxis pastoral de los frailes siempre optó porque los ministros aprendieran las lenguas nativas para adoctrinar a los indios. Tal práctica fue confirmada por el III Concilio Provincial Mexicano ${ }^{77}$, y sostenida por el arzobispo Aguiar durante sus visitas pastorales.

\section{DELEGACIÓN DE JURISDICCIÓN}

Trento normó la administración del sacramento del matrimonio con el fin de evitar los matrimonios clandestinos y establecer los impedimentos canónicos, en este sentido, los amancebados eran considerados pecadores públicos y transgresores sociales, por lo que era muy importante procurar que volvieran al estado de gracia y guardaran el correcto orden social ${ }^{78}$.

De manera ordinaria, era al obispo a quien le correspondía realizar todo el trámite matrimonial, y por delegación, a los jueces eclesiásticos, sin embargo, a causa de la peculiar situación de las Indias, la Sede Apostólica expidió, y el Real Consejo aprobó desde 1682 un breve en el que se permitía a los ministros de doctrina recibir las informaciones matrimoniales, hacer las amonestaciones y casar a sus fieles sin la licencia previa del obispo ${ }^{79}$.

Los jueces eclesiásticos, desde finales del siglo XVI, fueron una ampliación de la presencia de la mitra en el territorio arquidiocesano, pero la independencia de las misiones animadas por las órdenes mendicantes, lo impidió ${ }^{80}$. No obstante, el predecesor de Aguiar, el arzobispo-virrey, Payo Enríquez de Ribera, llegó

\footnotetext{
indios, México 15 marzo 1689, fol. 4r.

77 Cfr. D. TANCK de Estrada, "Castellanización, política y escuela de indios...", págs. 701-703.

${ }^{78}$ Cfr. Dolores Enciso, "Matrimonio, bigamia y vida cotidiana en Nueva España”, Dimensión Antropológica, vol XVII, México, Instituto Nacional de Antropología e Historia, 2009, disponible en $<$ http://www.dimensionantropologica.inah.gob.mx/?p=1186> [13.04.2012].

${ }^{79}$ Cfr. AGI, Instituciones Metropolitanas del Consejo de Indias, México 338, Cartas y expedientes de los arzobispos de México, El arzobispo al Rey sobre la cédula y bula del papa en la que se permite que los curas puedan casar a los feligreses sin licencia del obispo, México 20 de agosto de 1684, fols. 1r-2r.

${ }^{80}$ Cfr. Jorge Traslosheros, "Para historiar los tribunales eclesiásticos ordinarios de la provincia eclesiástica de México en la Nueva España. Los contextos institucionales, las fuentes y su tratamiento", en Doris Bienko y Berenice Bravo (coords.), De sendas, brechas y atajos. Contexto y crítica de la fuentes eclesiásticas, siglos XVI-XVIII, México, Escuela Nacional de Antropología e Historia, 2008, págs. 89-92.
} 
a nombrar 18 funcionarios eclesiásticos para atender los juzgados eclesiásticos existentes en las provincias del arzobispado ${ }^{81}$.

El rey interpeló a Aguiar sobre los beneficios que reportaba la aplicación de la bula que permitía a los doctrineros levantar las informaciones matrimoniales. La respuesta del arzobispo fue favorable, fruto de su primera salida a visita ${ }^{82}$.

Sin aludir al hecho de que el amasiato era más común de lo que se puede pensar en una sociedad cristiana como la de la Nueva España, el arzobispo mismo reconoció, a través de su recorrido por los pueblos, el estado de abandono pastoral de sus fieles a causa de una deficiente organización administrativa que no cubría el amplio territorio arquidiocesano, y quiso auxiliarse de las medidas que ya habían sido procuradas por la Iglesia y aprobadas por el Real Patronato con el objeto de resarcir el daño y ofrecer una mejor atención pastoral.

En la cuarta cordillera dejó provisiones similares a los curas ministros extendiendo estas licencias al guardián o prior, y aún a los coadjuntores ${ }^{83}$. Estas mercedes suscitaron la modificación de la jurisdicción de algunos jueces eclesiásticos, a quienes les fue refrendado su cargo con la exclusión de actuar, en cuanto a las informaciones matrimoniales, en las doctrinas facultadas ${ }^{84}$.

De especial importancia resulta el juez de tribunal, Francisco de Olave, capellán del Ingenio de Santa Bárbara ${ }^{85}$. A él, el arzobispo le dio el grave encargo de verificar el cumplimento de los mandatos que habían quedado asentados en los Autos de la visita, tanto de las doctrinas como de las cofradías. Esta decisión le permitió a Aguiar dar continuidad a su gestión más allá de la cuarta cordillera misma por medio un juez eclesiástico como una presencia extendida de la sede.

Francisco de Aguiar no desacreditó la preponderancia de las importantes órdenes mendicantes ni impuso su legítima autoridad episcopal, sino que medió para que se evitaran conflictos entre ambos cuerpos eclesiásticos que se superponían. Esto, además de mostrar que la centralización no fue una característica

\footnotetext{
${ }^{81}$ Cfr. Rodolfo Aguirre, "El establecimiento de los jueces eclesiásticos en las doctrinas de indios. El arzobispado de México en la primera mitad del siglo XVIII»”, en Historia crítica (2008), Colombia, Universidad de los Andes, págs. 15-19, disponible en <http://historiacritica.uniandes.edu. co/view.php/548/view.php> [12.02.2012].

${ }^{82}$ Cfr. AGI, Instituciones Metropolitanas del Consejo de Indias, México 338, Cartas y expedientes de los arzobispos de México, El arzobispo al Rey sobre la cédula y bula del papa en la que se permite que los curas puedan casar a los feligreses sin licencia del obispo, México 20 de agosto de 1684, fols. 1r-v.

${ }^{83}$ Cfr. III-LVFAS, fols. 138v-139r; 148v-149r; 163v-164r; 173r; 186v; 196r-v; 202v-203r; 224rv; 247v-248r; 252 r-v; 283v-284r; 296. En el arzchivo de la parroquia de Santa María Ozumba se encontró un testimonio del cura ministro, quien hizo buen uso de la facultad despachada por el arzobispo: cfr. AHPSMO, Sacramental, Matrimonios, 1668-1836, exp 1, fols. 1r-v.

${ }^{84}$ Cfr. III-LVFAS, fols. 22r-v; 48r; 78v; 86r; 135v; 190r; 301r.

${ }^{85}$ Cfr. III-LVFAS, fols. 77r; 150r.
} 
de su gobierno, debe reconocerse como notable si se toma en cuenta que desde el siglo XVI los conflictos entre regulares y seculares habían sido continuos y violentos.

\section{AUSENCIA DE LA SEDE-CURIA ITINERANTE}

Las cinco cordilleras que recorrió Aguiar durante más de cuatro años provocaron que estuviera ausente de la mitra por períodos prolongados y continuos. El responsable de los asuntos de la curia, en ausencia del arzobispo, era Diego de la Sierra, provisor, juez fiscal y vicario general del arzobispado ${ }^{86}$, quien a pesar de gozar de la misma jurisdicción que Francisco de Aguiar, no podía ser el contrapeso de autoridad que el arzobispo significaba en la sociedad novohispana.

En la cuarta cordillera el arzobispo atendió, a la distancia, dos asuntos importantes de la sede. El primero sucedió el 12 de diciembre de 1686; envió un despacho al notario público y al oficial mayor del juzgado de testamentos, capellanías y obras pías de la Audiencia arzobispal para ordenarles que no abusaran de su ausencia y asistieran a trabajar cada día, desde las ocho y media de la mañana hasta el mediodía y por la tarde, de las tres a las seis, exceptuando los días festivos o por enfermedad ${ }^{87}$. El segundo hecho sucedió el 11 de enero de 1687, cuando nombró a su nuevo provisor de indios a favor del doctor don Francisco de Aguilar, presbítero y catedrático de vísperas de Leyes, a causa de la muerte del anterior, García de León ${ }^{88}$.

Aguiar se hizo acompañar de un discreto número de familiares, que constituyeron su pequeña curia itinerante. Entre ellos, el intérprete del arzobispado, Juan de Mendoza, quien tradujo las respuestas de los jóvenes indios de la doctrina, a quienes el arzobispo interrogaba ${ }^{89}$.

Su capellán y crucero, el presbítero bachiller Luis López ${ }^{90}$, ofició en la Misa vespertina de Aguinaldo de la Virgen María el sábado 21 de diciembre en la doctrina agustina de San Juan Bautista Tlayacapa, cantó los ofrecimientos a la Santísima Virgen María en los rosarios del mes de enero, animó con su notable

\footnotetext{
${ }^{86}$ Cfr. B. Rosales, Diario..., pág. 204; A. Robles, Diario..., pág. 56. Diego de la Sierra ostentó el cargo de provisor desde el inició de la gestión de Francisco de Aguiar hasta febrero de 1692 cuando falleció de manera súbita. A la siguiente semana de su fallecimiento, el arzobispo nombró al canónigo Antonio Aunsibay y Anaya como nuevo provisor; cfr. A. Robles, Diario..., págs. 32; 36; 240. ${ }^{87}$ III-LVFAS, fol. $13 \mathrm{v}$.

${ }^{88}$ Cfr. Cfr. III-LVFAS, fols. 84r-85r; A. Robles, Diario..., pág. 36.

${ }^{89}$ Cfr. III-LVFAS, fol. 9v. Juan de Mendoza era intérprete del arzobispado. Aguiar se lo llevó en su primera salida rumbo a Tampico, porque además de saber el mexicano también dominaba el otomí; cfr. B. Bravo y M. A. Pérez, "Tiempos y espacios religiosos novohispanos...", en o.c., pág, 72 ${ }^{90}$ Cfr. III-LVFAS, fols. 32v; 78r; 96v; 101r; 123r; $123 \mathrm{v}$.
} 
voz las procesiones nocturnas y portaba la cruz alta durante la solemne recepción del obispo a la entrada de cada pueblo.

El sacerdote jesuita José Capetillo, capellán y predicador, pronunció sermones tanto en castellano como en mexicano en las pláticas de misión que se decían todos los días por las tardes y durante las procesiones nocturnas ${ }^{91}$. Cantó la misa en la solemnidad de la Natividad de María, el domingo 8 de diciembre en Santiago de Chalco y predicó en la eucaristía en honor de la Señora de la Candelaria el 2 de febrero en Tochimilco ${ }^{92}$. Al final de la cuarta cordillera fue promovido por el señor arzobispo para predicar y confesar en castellano y mexicano e incluso confesar religiosas sujetas a la obediencia del prelado ${ }^{93}$.

Francisco Ayerra fungió como juez de testamentos, capellanías y obras pías, matrimonios, causas civiles y criminales ${ }^{94}$. El asunto que atendió con mayor recurrencia fue el de conceder licencias con dispensa de banas $^{95}$, para que las parejas pudiesen contraer matrimonio ${ }^{96}$. Además de sus deberes jurídicos, tam-

${ }^{91}$ Cfr. III-LVFAS, fols. 4r; 15r; 31v; 39r; 46r; 61r; 75v; 77r; 87r; 96v; 108v; 120v; 123v; $128 \mathrm{r}$; 130v; 144r; 149r; 153r; 156r; 176v; 179r; $180 \mathrm{r}-\mathrm{v} ; 186 \mathrm{v} ; 187 \mathrm{v} ; 189 \mathrm{v} ; 195 \mathrm{r} ; 199 \mathrm{v} ; 211 \mathrm{r} ; 217 \mathrm{r} ; 226 \mathrm{r}$; 234v; 237v; 246v; 260v; 263v; 266r; 269v-270r; 273v; 293r. José Errada Capetillo, nació en México alrededor de 1641, ordenado presbítero hacia 1659 y misionero entre los tepehuanes en 1661. En el año de 1672, le fue instruido un proceso inquisitorial a causa de un sermón con ocasión de la procesión del Nazareno en el colegio de la Compañía en Zacatecas, en el que al parecer incluyó proposiciones poco ortodoxas, sin recibir condena alguna. Luego de este incidente, pronunció sus votos como coadjuntor espiritual. En 1676 fue enviado como procurador y ministro al colegio de Puebla de los Ángeles. Cuando Francisco de Aguiar llegó a la Ciudad de México, era operario de la casa de La Profesa; cfr. Francisco Zambrano, Diccionario Bio-Bibliográfico de la Compañía de Jesús en México. Siglo XVII (1600-1699), t. IV, México, Jus, 1965, pág. 626; AGN, Instituciones coloniales, Inquisición, vol. 617, exp. 3, fols. 399-431v.

92 III-LVFAS, fols. 4v-5r; 138r-v. El P. Capetillo continuó predicando en mexicano bajo la tutela del arzobispo; cfr. F. ZAmBRAno, Diccionario Bio-Bibliográfico..., pág. 627.

${ }^{93}$ Cfr. III-LVFAS, f. 303v. Esta ampliación de licencia en ambas lenguas para confesar hombres, mujeres y religiosas, también la concedió a fray Juan de Santillán, predicador franciscano de la doctrina de Santiago de Chalco; cfr. III-LVFAS, fol. 8v.

${ }^{94}$ Originario de Puerto Rico, fue gran amigo de Carlos Sigüenza y Góngora, quien le llama la mitad de su alma en su obra Triunfo parténico (1683). El doctor Ayerra fue capellán del Real Convento de Jesús María y primer Rector del Seminario Conciliar en 1697. Cuando el arzobispo no pudo salir más a visita, lo nombró visitador del arzobispado. Falleció en 1708, a los 78 años de edad; cfr. José M. Beristain de Souza, Biblioteca Hispanoamericana septentrional 1, México, Universidad Nacional Autónoma de México, 1980, pág. 131; J. Muriel, "El Arzobispo Francisco de Aguiar y Seijas", en o.c., pág. 23.

${ }^{95}$ Las banas eran las notificaciones hechas por la autoridad eclesiástica a los fieles sobre la próxima celebración de un matrimonio. Tenían dos finalidades: por un lado, hacer pública proclamación de los matrimonios católicos y por otro, descubrir impedimentos para prevenir matrimonios nulos o ilícitos. Cfr. "Bans de mariage", en R. NAz (dir.), Dictionnaire de Droit canonique, t. 2, Paris, Librairie Letouzey et Ané, 1937, pág. 90.

96 El total de las licencias llegó casi a 80 ; cfr. III-LVFAS, fols. 3r-314v. 
bién compartió predicación en castellano, con el padre Capetillo durante las procesiones marianas ${ }^{97}$.

Felipe Desa y Ulloa, presbítero, por su carácter de Notario apostólico de visita, fue el encargado de la redacción del Libro ${ }^{98}$, el cual, en su mayor parte está escrito en tercera persona; sólo cuando él mismo intervino en el desarrollo de los hechos, habló en primera persona. Sobre todo cuando publicaba el Edicto de visita al llegar a cada población ${ }^{99}$. Dio fe en los diversos despachos del arzobispo, tales como la refrenda en el cargo de los jueces eclesiásticos, la expedición de decretos o nombramientos, así como la procuración de alguna dispensa reservada. Al final de cada una de estas providencias, su firma quedó plasmada ${ }^{100}$.

Francisco de Aguiar precisó de gente que estuviera al pendiente de aspectos que evidentemente quería atender: la predicación, el culto, la administración del derecho y el adoctrinamiento cristiano. En una palabra, gobernó e impartió justicia; ejerció su potestad de orden y jurisdicción como obispo ${ }^{101}$.

La sencillez de este cortejo debió causar impacto en los pobladores. Además, el arzobispo no llevaba carruaje, sino que se transportaba a caballo o a pie, en tanto que, en las zonas lacustres, lo hizo en canoa ${ }^{102}$. En el Edicto de visita, el arzobispo había hecho ya manifiesta su voluntad de no hacer gastos innecesa$\operatorname{rios}^{103}$.

Al igual que Aguiar, Manuel Fernández de Santa Cruz, siempre solicitó que en las visitas su mesa fuera frugal y no mayor a tres viandas. Si acaso le servían un banquete excesivo, el obispo decía que se iría de aquel pueblo si no se obedecía lo que había mandado ${ }^{104}$.

En cambio, el arzobispo fray Alonso de Montúfar, envuelto en sus ásperas discusiones con los religiosos sobre la cuestión del pago de diezmos de los indios, llegó a quejarse ante el Real Consejo que las pocas entradas a las arcas eclesiásticas no le había permitido presentarse en las visitas acompañado de un séquito digno del alto oficio que ostentaba ${ }^{105}$.

\footnotetext{
${ }^{97}$ Cfr. III-LVFAS, fols. 176v, 180v; 195r.

98 Cfr. III-LVFAS, fol. 2v.

${ }^{99}$ Cfr. III-LVFAS, fols. 3v-4r.

${ }^{100}$ Cfr. III-LVFAS, fols. 13v; 22 r-v; 47v-48r; 58r; 104v; 301r.

${ }^{101}$ Cfr. Jean Gaudemet, Storia del diritto canonico. Ecclesia et Civitas, Milano, San Paolo, 1998, pág. 480.

${ }^{102}$ Cfr. III-LVFAS, fols. 55-v; 96v; 256r; 276r.

${ }^{103}$ Cfr. III-LVFAS, fol. 2 r.

${ }^{104}$ Cfr. M. Torres, Dechado de príncipes eclesiásticos..., pág. 139.

${ }^{105}$ Cfr. M. LundBerg, Unificación y conflicto..., pág. 185.
} 


\section{DECISIONES CONCILIADORAS}

Francisco de Aguiar medió entre la doctrina dominica de ChimalhuacánChalco y la de Santa María Ozumba, atendida por franciscanos ${ }^{106}$. Dada la proximidad entre ambas entidades, los feligreses pasaban de una a otra para curarse de sus enfermedades. Sin embargo, al fallecer las personas, se les enterraba en la doctrina donde no estaba su residencia, por lo que no pagaban los emolumentos debidos a su parroquia de origen.

Para evitar querellas, el prelado determinó que los ministros se trasladaran a la doctrina vecina para sacramentar y enterrar a sus fieles y evitar que se defraudaran sus derechos parroquiales. Esta resolución era conciliadora, pero atrevida, porque permitía a los religiosos de una doctrina ingresar a otra, sin embargo, instó a ambas órdenes religiosas a compartir jurisdicción en aras del bien espiritual del rebaño.

Otro hecho sucedió durante el encuentro que sostuvo con Manuel Fernández de Santa Cruz en Cuautla de las Amilpas. Ambos prelados acordaron que el cura beneficiado de Xolalapa, perteneciente al obispado de Puebla de los Ángeles, atendiera al Real de Cuautla, de la arquidiócesis de México ${ }^{107}$. Fue una cesión de jurisdicción sin litigios previos para procurar la atención pastoral del rebaño.

En general, Aguiar y Seijas fue poco afecto a involucrarse en procesos canónicos y civiles, pero tres años antes de su muerte, el virrey, Conde de Galve, escribió a España sobresaltado a causa de un inédito pleito entre el arzobispo y la Audiencia, siendo que jamás se había visto al prelado involucrado en litigios públicos, dado lo calmo de su ánimo ${ }^{108}$.

\section{PASTOR DE ALMAS}

Al comparar el edicto de visita de Francisco de Aguiar con los de los obispos de Guadalajara, Juan Ruiz Colmenero (1658) y Juan de Santiago y León Garabito $(1678)^{109}$, se puede afirmar que el arzobispo sólo justificó su ministerio en las directrices de la reforma tridentina y no en la merced real que recibió, ya que la

\footnotetext{
${ }^{106}$ Cfr. III-LVFAS, fols. 188r-v.

${ }^{107} \mathrm{Cfr}$. III-LVFAS, fols. 56v-58r.

${ }^{108}$ Cfr. AGI, Instituciones Metropolitanas del Consejo de Indias, México 62, Sobre algunos roces entre el arzobispo y la Audiencia de México, 8 de mayo de 1695, fol. 2v.

${ }^{109}$ Cfr. "Edicto y Carta Pastoral de Prevención para la vista pastoral del obispo Juan Ruiz Colmenero", 15-16 de marzo de 1658, en Valentina GARZA y Juan Manuel PÉrEZ, (paleografía, introducción y notas), Las Visitas pastorales de Mazapil 1572-1856, México-Zacatecas-San Luis Potosí, CIESAS-Municipio de Mazapil-Archivo Histórico del Estado "Lic. Antonio Rocha Cordero"-Instituto Zacatecano de Cultura "Ramón López Velarde", 2007, pág. 132; "El Libro de Visita pastoral del obispo Garabito o semblanza de la Nueva Galicia en 1678”, pág. 38.
} 
única referencia de su vínculo con la corona está en la intitulación del edicto, en la que afirma ser arzobispo de México, del consejo del rey, por la gracia de Dios y de la Santa Sede Apostólica ${ }^{110}$.

Monseñor Juan Ruiz Colmenero, en su edicto de visita sí resaltó notablemente su vínculo con el Real Patronato, ya que se presenta a sí mismo como pastor encargado del rebaño, cuyo primer responsable es el rey, el cual le ha facultado para enmendar y castigar los abusos que alteran las buenas costumbres ${ }^{111}$. Por su parte, el obispo Garabito añadió a su edicto una real cédula en la que el monarca le solicitaba corregir todo tipo de abusos de las autoridades civiles sobre los indios ${ }^{112}$.

El Libro de visita de Aguiar no refiere ningún tipo de relación particular de éste con las autoridades civiles de los pueblos, únicamente se les menciona como parte de las comitivas de recepción y en algunas ocasiones se dan sus nombres, así como el cargo que ostentaban. En cambio, la misma fuente refiere la visita que hizo el obispo Manuel Fernández de Santa Cruz, al alcalde mayor del partido de Cuautla, el capitán don Juan de Padilla y Arnao ${ }^{113}$.

Ahora bien, el saludo que el arzobispo da en el edicto de visita es muy sencillo y de notable influencia paulina ${ }^{114}$. El saludo paulino de Aguiar en su anunciaba el carácter apostólico y misionero de su cuarta salida.

\section{CONCLUSIONES}

Don Francisco de Aguiar y Seijas y Ulloa, betanceiro de origen, desde muy joven vivió dentro de un ambiente clerical y reformado en la arquidiócesis compostelana, tanto en el Colegio Mayor de Santiago como en el cabildo catedralicio jacobeo.

Se valió de la gran autoridad eclesiástica que la Iglesia universal le había confiado para mantener a la arquidiócesis de México bajo las directrices del Concilio de Trento, ya que él era el último responsable de velar por la salvación del rebaño bajo su custodia. Como obispo indiano, también se encontraba bajo el régimen del Patronato, por lo que no sólo era un ministro eclesiástico sino también un funcionario real. De entre ambas, prefirió la primera. En efecto, la

\footnotetext{
${ }^{110} \mathrm{Cfr}$. III-LVFAS, fol. $1 \mathrm{r}$.

${ }^{111}$ Cfr. "Edicto y Carta Pastoral de Prevención para la vista pastoral del obispo Juan Ruiz Colmenero”, 22 marzo-13 junio 1648, en V. Garza y J. M. PÉrEZ, (paleografía, introducción y notas), Las Visitas pastorales de Mazapil..., págs. 109-110.

${ }^{112}$ Cfr. "El Libro de Visita pastoral del obispo Garabito...", pág. 38.

${ }^{113}$ Cfr. III-LVFAS, fols. 55r-61r.

${ }^{114}$ III-LVFAS, fols. 1r-2r.
} 
identidad bajo la cual ejerció su gobierno episcopal fue la de pastor de almas y no sobre la base de una identificación regalista o cortesana.

Por su ser de ministro eclesiástico, resolvió que el medio privilegiado para desplegar su gestión episcopal era hacer la visita pastoral por él mismo. Por medio de ella se percató personalmente del estado que guardaban las personas y las cosas dentro del territorio arquidiocesano, de las necesidades y aciertos pastorales. Buscó corregir abusos disciplinares y administrativos para reorientar la pastoral. Su preocupación primordial fueron las personas más que los bienes muebles e inmuebles.

Optó por hacer de la visita una misión popular con el fin de mudar el comportamiento de las personas. Mostró preocupación preferencial por dos grupos sociales: los esclavos negros de los ingenios y trapiches, y las parejas amancebadas. A favor de los cuales expidió múltiples permisos que además afianzaron la presencia del clero secular y dinamizaron la pastoral en las doctrinas atendidas por los religiosos.

Por lo anterior y por haber dejado en la persona de su provisor el gobierno de la sede en su ausencia, así como por haber proveído a un juez eclesiástico como encargado de verificar la ejecución de sus mandatos dados en la cuarta cordillera, se puede decir que Francisco de Aguiar no gobernó con características centralistas sino de delegación.

Otra gran prioridad de su ministerio fue la de administrar el sacramento de la confirmación, exclusivo de su potestad episcopal y por lo cual no recibió ofrenda alguna. Además, respetuoso de la república de los indios, confirmó a los fiscales, laicos responsables de la animación religiosa de sus comunidades sin exigirles enseñar la religión en castellano, como estaba ordenado por la corona. Esto último es un signo más de que su criterio de discernimiento era la mejor atención pastoral de la grey; por tanto, en ocasiones no resolvía según la real voluntad, sino de acuerdo con su tacto pastoral, pero sí recurría a ella para implorar alguna merced a favor de los fieles.

Para afrontar las tensiones que su opción preferencial por la cura de las almas ocasionaba no sólo con el rey, sino también con los ministros y clérigos, Francisco de Aguiar y Seijas contaba con un carácter sosegado que le ayudó a resolver conflictos y a suavizar enemistades, sin acudir al recurso del litigio público.

A su carácter flemático, se deben añadir sus atributos religiosos como hombre de fe y oración. Destacó por mostrarse como un obispo de costumbres austeras y disciplinadas; ausente de los oropeles mundanos, pero lleno de celo pastoral en medio de la mies.

Queda pendiente hacer un estudio de todas sus visitas, incluyendo las que efectuó en Michoacán para seguir la evolución de su trayectoria como visitador. 
También es posible realizar una investigación de la visita general a la arquidiócesis de México, incluyendo el trabajo de hallar el libro de su inconclusa quinta cordillera.

Del mismo modo, se puede inquirir sobre su proyecto de gobierno en el que se profundizaría la administración de la justicia eclesiástica y los vínculos con el cabildo catedralicio, así como la interacción con otros cuerpos sociales, tanto eclesiales como civiles.

Por lo que toca a los datos que aporta el Libro de visita, éste contiene copiosa información sobre las órdenes religiosas y las cofradías. La detallada descripción de las ceremonias, ornamentos, vasos y lugares sagrados permitirían recomponer el cuadro litúrgico y de ornamentación de la época. Los padrones ofrecen abundantes datos, viables para estudios de antropología social. Y en general, la descripción de lo acaecido en cada doctrina auxiliaría en la reconstrucción etnográfica de ciertas poblaciones o regiones.

\section{ANEXo DOCUMENTAL}

1686, diciembre, 9.- Totolapan.

Por ser conveniente

Al bien espiritual y temporal de mis ovejas

$Y$ también que pueda $V$ arzobispo quitar los muchos días de precepto que impusieron sus antecesores: pues con el grande número de ellos, los pobres oficiales no pueden ganar el sustento para sus familias; y los poco temerosos de Dios se arreglan al quebrantamiento del precepto, de tal manera que en las haciendas de minería, trapiches, ingenios y obrajes no cesan las obras serviles ni aún en los días dominicales y se cometerán pecados en la especie de no guardar las fiestas de que estoy bien noticiado en las tres cordilleras de visita y en la cuarta en que estoy entendiendo, sin que basten edictos de visita, platicas ni pastorales amonestaciones para detenerlos: consigamos el que no sea tan grande el número de estos días festivos para remediar algo ya que no se puede todo el óbice que se me puso al intento de publicar la dicha Bulla de Urbano fue el no estar pasada por el Consejo de Indias, suplico a VM se sirva declararlo o quitarlo pues he cesado de este intento por no causar alguna discordia y conservar la paz con los ministros de VM.

[Firma del arzobispo] 
AGI, Instituciones Metropolitanas del Consejo de Indias, México 338, Cartas y expedientes de los arzobispos de México, el arzobispo pide que se mande Real Cédula en la que se le permita publicar la bula de Urbano VIII en donde se marcan las fiestas de precepto, fols. 1r-10v, castellano, letra humanística.

Observaciones: En los fols. 2r-3v, con fecha del 30 de agosto de 1687 se indica que la carta fue entregada a fray Alejo de Foronda, dominico, para que la hiciera llegar al Consejo de Indias y cómo el arzobispo le entregó el memorial para tal efecto. En el fol. 10v está el acuse de revisado en el Consejo el 18 de noviembre de 1687.

\section{BIBLIOGRAFÍA}

Aguirre, Rodolfo, "El establecimiento de los jueces eclesiásticos en las doctrinas de indios. El arzobispado de México en la primera mitad del siglo XVIII»”, Historia crítica (2008), Colombia, Universidad de los Andes, págs. 15-19, disponible en <http://historiacritica. uniandes.edu.co/view.php/548/view.php> [Consulta: 12.02.2012].

Alberigo, Giuseppe (ed.), Conciliorum Oecumenicorum Decreta, Bologna, Edizioni Dehoniane, 1991.

Beristain de Souza, José M., Biblioteca Hispanoamericana septentrional 1, México, Universidad Nacional Autónoma de México, 1980.

Bienko, Doris y Bravo, Berenice (coords.), De sendas, brechas y atajos. Contexto y crítica de la fuentes eclesiásticas, siglos XVI-XVIII, México, Escuela Nacional de Antropología e Historia, 2008, págs. 197-209.

Cappelli, Adriano, Cronologia. Cronografia e Calendario perpetuo, Milano, HOEPLI, 19987.

Carrillo, Alberto, A., Michoacán en el otoño del siglo XVII, Zamora, El Colegio de Michoacán, 1993.

Carrillo, Alberto (ed.), Manuscritos del Concilio tercero provincial mexicano (1585), t. III, vol. 1, Zamora, El Colegio de Michoacán, 2009.

Corpus juris canonici emendatum et notis illustratum, pars. I, vol. I, Romae, Gregorii XIII. pont. Max. iussu editum, 1582, disponible en <http://digital.library.ucla.edu/canonlaw/> [Consulta: 27.06.2011].

Coulet, Nicole, Les visites pastorales, Turnhout-Belgium, Brepols, 1977.

Cuevas, Mariano, Historia de la Iglesia en México 1600-1699, t. III, México, Cervantes, $1942^{4}$.

Dosse, François, El arte de la biografía, México, Universidad Iberoamericana, 2007.

Dougnac, Antonio, Manual de historia del Derecho Indiano, México, Instituto de Investigaciones Jurídicas-Universidad Nacional Autónoma de México, 1994.

"El Libro de Visita pastoral del obispo Garabito o semblanza de la Nueva Galicia en 1678", Boletín eclesiástico, Guadalajara, Órgano oficial de la Arquidiócesis de Guadalajara, vol. 120/ 1 (2009), págs. 37-39.

El sacrosanto y ecuménico concilio de Trento, tr. Ignacio López de Ayala, París-México, Librería de CII. Bouret, s/f.

Enciso, Dolores, "Matrimonio, bigamia y vida cotidiana en Nueva España”, Dimensión Antropológica, vol. XVII, México, Instituto Nacional de Antropología e Historia, 2009, 
disponible en <http://www.dimensionantropologica.inah.gob.mx/?p=1186> [Consulta: 13.04.2012].

Fantappiè, Carlo, "Il concilio di Trento e la reforma pastorale", en Introduzione storica al diritto canonico, Bologna, il Mulino, 2003.

Garza, Valentina y Pérez, Juan Manuel (paleografía, introducción y notas), Las Visitas pastorales de Mazapil 1572-1856, México-Zacatecas-San Luis Potosí, CIESAS-Municipio de Mazapil-Archivo Histórico del Estado "Lic. Antonio Rocha Cordero"-Instituto Zacatecano de Cultura "Ramón López Velarde", 2007.

Gaudemet, Jean, Storia del diritto canonico. Ecclesia et Civitas, Milano, San Paolo, 1998.

Hera, Alberto, Iglesia y corona en la América española, Madrid, MAPFRE, 1992.

Horn, Rebeca, Postconquest Coyoacan. Nahua-Spanish relations in Central Mexico, 15191650, Stanford, Stanford University Press, 1997.

Iglesias, Arturo, El cabildo catedralicio de Santiago de Compostela en el siglo XVI: aspectos funcionales y sociológicos de una élite eclesiástica, Santiago de Compostela, Universidad de Santiago de Compostela, 2010.

Jalpa, Tomás, La sociedad indígena en la región de Chalco durante los siglos XVI y XVII, México, Instituto Nacional de Antropología e Historia, 2009.

Konetzke, Richard (ed.), Jahrbuch für Geschichte von Staat Wirtschaft und Gesellschaft Lateinamerikas, Wien, Böhlau Verlag Köln, 1980.

Lezamis, Joseph, Breve relación de la vida y muerte del Ilmo. y Rmo. Sr. Dr. D. Fco. de Aguiar y Seixas, que está en la vida del apóstol Santiago el Mayor, México, María de Benavides, 1699.

López, Antonio, Historia de la Santa A. M. Iglesia de Santiago de Compostela, t. IX, Santiago de Compostela, Seminario Conciliar Central, 1907.

Lundberg, Magnus, Unificación y conflicto. La gestión episcopal de Alonso de Montúfar OP, Arzobispo de México, 1554-1572, tr. Alberto Carrillo Cázares, Zamora, El Colegio de Michoacán, 2009.

Mayer, Alicia y De la Torre, Ernesto (eds.), Religión Poder y Autoridad en la Nueva España, México, Universidad Nacional Autónoma de México, 2004.

Melquíades, Andrés, La teología española en el siglo XVI, t. II, Madrid, Biblioteca de Autores Cristianos, 1977.

Miño, Manuel, El mundo novohispano. Población, ciudades y economía, siglos XVII y XVIII, México, Colegio de México-Fondo de Cultura Económica, 2001.

Muriel, Josefina (coord.), El Arzobispo Francisco de Aguiar y Seijas, México, CARSO, 2000.

Muriel, Josefina, La sociedad novohispana y sus colegios de niñas. Fundaciones del siglo XVI, t. I, México, Instituto de Investigaciones Históricas-Universidad Nacional Autónoma de México, 2004.

Naz, Raoul (dir.), Dictionnaire de Droit canonique, t. II, Paris, Librairie Letouzey et Ané, 1937.

Pérez, Juan Manuel, Xochimilco ayer, México, Instituto Mora, 2002.

Pontificale Romanum Clementis VIII Pont. Max. iussu restitutum atque, Leonardi Parasoli \& Sociorum (ed.), Roma, Giacomo Luna (imp.), 1595. 
Recopilación de las Leyes de Indias, Archivo Digital de la legislación en el Perú, disponible en <http://www.congreso.gob.pe/ntley/LeyIndiaP.htm> [Consulta: 01.03.2011].

Ricard, Robert, La conquista espiritual de México. Ensayo sobre el apostolado y los métodos misioneros de las órdenes mendicantes en la Nueva España de 1523-1524 a 1572, México, Fondo de Cultura Económica, 1999.

Robles, Antonio, Diario de sucesos notables (1665-1703), t. II, México, Porrúa, 1972 2.

Rosales, Bartolomé, Diario 1683-1688, en Estudios de historia novohispana Vol. XXXVIII (2008), transcripción y notas Benedetta Albani, México, Universidad Nacional Autónoma de México, 165-207.

Santiró, Ernest, "Plata y privilegios: el Real de Minas de Huautla, 1709-1821", en Estudios de Historia Novohispana 26 (2002), México, Instituto de Investigaciones Históricas, Universidad Nacional Autónoma de México, págs. 85-123.

Santos, Carlos, "Un volumen de constituciones sinodales compostelanas del siglo XVII en la Biblioteca del Seminario Mayor Divino Maestro de Ourense", Auriensia 12 (2009) págs. 233-283.

Silva, Natalia, "El uso de los baños temascales en la visión de dos médicos novohispanos. Estudio introductorio y transcripción documental de los informes de 1689", en Historia Mexicana Vol. LII/1 (2002), México, Revista Trimestral publicada por el Centro de Estudios Históricos de El Colegio de México, págs. 5-30.

Tanck de Estrada, Dorothy, "Castellanización, política y escuela de indios en el arzobispado de México a mediados del siglo XVIII", en Historia Mexicana Vol. XXXVIII/4 (1989), México, Revista Trimestral publicada por el Centro de Estudios Históricos de El Colegio de México, págs. 701-703.

Tomás de Aquino, Suma de teología IV, Parte II-II (b), Madrid, Biblioteca de Autores Cristianos, Madrid $1997^{2}$.

Torres, Miguel de, Dechado de príncipes eclesiásticos. Que dibujó con su exemplar, virtuosa y ajustada vida el Ilust. Y Exc. Señor Doctor D. Manuel Fernandez de S. Cruz, y Sahagún, ed. facsimilar, México, Sociedad Mexicana de Bibliófilos, 1999.

Troitiño, Manuel, Vida del Ilmo. Sr. Don Francisco de Aguiar y Seixas, Santiago, E.U.C., 1951.

Vázquez, Antonio, Descripción de la Nueva España, Mariano Cuevas (ed.), México, Patria, 1944.

Vera, Gumersindo (coord.), Los historiadores y la Historia para el siglo XXI, México, Escuela Nacional de Antropología e Historia, 2006.

Zambrano, Francisco, Diccionario Bio-Bibliográfico de la Compañía de Jesús en México. Siglo XVII (1600-1699), t. IV, México, Jus, 1965. 